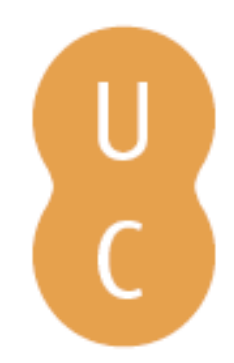

\title{
pommalina
}

\section{Fabulário: (re)contando mitos}

Autor(es): $\quad$ Santos, Rosana Baptista dos

Publicado por: Imprensa da Universidade de Coimbra

URL

persistente: URI:http://hdl.handle.net/10316.2/37033

DOI: $\quad$ DOI:http://dx.doi.org/10.14195/978-989-26-0548-7_13

Accessed : $\quad$ 26-Apr-2023 08:57:58

A navegação consulta e descarregamento dos títulos inseridos nas Bibliotecas Digitais UC Digitalis, UC Pombalina e UC Impactum, pressupõem a aceitação plena e sem reservas dos Termos e Condições de Uso destas Bibliotecas Digitais, disponíveis em https://digitalis.uc.pt/pt-pt/termos.

Conforme exposto nos referidos Termos e Condições de Uso, o descarregamento de títulos de acesso restrito requer uma licença válida de autorização devendo o utilizador aceder ao(s) documento(s) a partir de um endereço de IP da instituição detentora da supramencionada licença.

Ao utilizador é apenas permitido o descarregamento para uso pessoal, pelo que o emprego do(s) título(s) descarregado(s) para outro fim, designadamente comercial, carece de autorização do respetivo autor ou editor da obra.

Na medida em que todas as obras da UC Digitalis se encontram protegidas pelo Código do Direito de Autor e Direitos Conexos e demais legislação aplicável, toda a cópia, parcial ou total, deste documento, nos casos em que é legalmente admitida, deverá conter ou fazer-se acompanhar por este aviso.

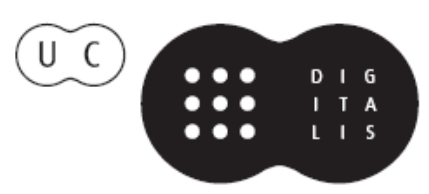


do Tempo e da História

- Mário de Carvalho e a reflexáo metaficcional sobre o futuro do romance - Sátiva e o cepticismo: configuração de personagens em Mário de Carvalho - Escrever tem arte e tem segredos... Era bom que trocássemos umas ideias sobre o assunto - O processo criativo em Era bom que trocássemos umas ideias sobre o assunto - Intertextualidade e metaficção em Fantasia para dois Coronéis e uma Piscina, de Mário de Carvalho - Trimalquiāo, os coronéis e a piscina: retrato impiedoso de um pais em crise $\bullet A$ Paixão do Conde de Fróis: paródia e subversão • "Como dizia o outro": a presença dos Clássicos em Mário de Carvalho - Cultura Clássica em Um

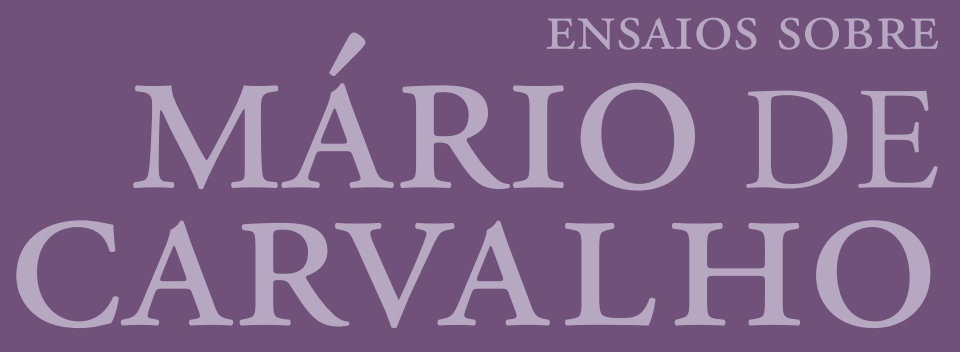

Maria de Fátima Silva Tereza Virgínia Ribeiro Barbosa COORD. IMPRENSA DA UNIVERSIDADE DE COIMBRA COIMBRA UNIVERSITY PRESS

elemento mouro como simbolo de alteridade $e$ barbárie em Um deus passeando pela brisa da 


\title{
Fabulário: (Re)Contando Mitos
}

\author{
Rosana Baptista dos Santos \\ Universidade Federal de Lavras
}


(Página deixada propositadamente em branco) 
Fabulário $^{1}$, de Mário de Carvalho, é uma coletânea de breves contos ${ }^{2}$ que, em oposição aos de A inaudita Guerra da Avenida Gago Coutinho, caracteriza-se mais amplamente pela forma dialogada. A estrutura e o conteúdo dos textos, relacionados ao próprio título da edição que encerra uma potencialidade ficcional, indicam uma composição literária fantástica $\mathrm{e}$, às vezes, non sense. Duas temáticas são recorrentes nos contos: a viagem a lugares diversos e exóticos e o encontro com civilizaçóes ou sujeitos 'diferentes' do que tradicionalmente se conhece, qualquer uma delas sugestivas de uma mesma necessidade de fuga do simples cotidiano. Além desses temas, outro procedimento de criação literária sistematicamente adotado pelo autor é o estabelecimento de um diálogo com a história e com textos clássicos greco-latinos. Em algumas obras, como Quatrocentos mil sestércios, por exemplo, Mário de Carvalho reproduz todo um contexto histórico, cultural e literário de uma Lusitânia romanizada. Entretanto, em outros textos, como Fabulário ou Fantasia para dois coronéis e uma piscina, os temas inspirados na tradição e literatura greco-latina aparecem 'aqui' e 'ali', de maneira fragmentária ou diluídas pela narrativa de uma forma indireta, ligados a assuntos ou questóes da sociedade e do homem moderno.

Agradeço à Capes (Coordenação de Aperfeiçoamento Pessoal de Nível Superior) pela concessão de uma bolsa de Doutorado Sanduíche para a realização da pesquisa sobre a obra de Mário de Carvalho, na Universidade de Coimbra, que resultou na publicação deste capítulo de livro.

1 A palavra 'fábula', do latim fabula (cf. gr. dóxa), acumulava já tradicionalmente os sentidos seguintes: a) no uso comum, "comentários, conversas"; estas são nuances abonadas, por exemplo, pela expressão conviviales fabulae - "conversas de mesa", ou pela interjeição fabulae!, "Tretas! Histórias! Disparates!; b) adquiriu então, numa adaptação específica à terminologia literária, o sentido de "narrativa sem base histórica, lenda, ficção" (cf. gr. mythos); c) "peça de teatro", dramatização de uma história; d) ou, por fim, "conto, fábula, apólogo", especificando um tipo de narrativa marcadamente moralista; Gaffiot, s.u. Etimologicamente liga-se a for, fari- "dizer", "narrar". Mais tarde suscita a formação do denominativo fabulor, fabulari, "narrar em forma dialogada". Com a mesma família semântica estáo relacionados, com sentido equivalente, os adjetivos fabulosus e fabularis. Cf. Ernout, A., Meillet, A. (1939), Dictionnaire Étymologique de la Langue Latine. Paris, Librairie C. Klincksieck, s.u. Vide ainda a definição de fábula em Reis, C. (1997), Fábula. In: Biblos- Enciclopédia Verbo das Literaturas de Lingua Portuguesa. Lisboa, São Paulo, Verbo: 462-463, 459: "Do ponto de vista formal, a fábula constitui normalmente um relato breve e concentrado numa acção simples, desembocando num desenlace de claro recorte moralizador (...) pode ser aproximada do conto, sobretudo daquele cuja inserção popular denota uma autoria indeterminada e uma transmissão oral". Todas estas especificidades de sentido estão, de fato, presentes na coletânea de Mário de Carvalho.

2 ( ${ }^{3}$ 1997), Lisboa, Caminho. 
Mas há, ao longo desses textos, referências a procedimentos, entes ou mitos que evidenciam, de modo concreto, o jogo intertextual com os modelos gregos e latinos. Assim, centraremos nossa análise na viagem (fantástica, simbólica) empreendida pelos personagens e na figura do 'outro', o interlocutor do viajante, retomados, muitas vezes, de forma irônica, ao apontar para a busca do indivíduo por um lugar ideal, por seu 'deus' ou sua identidade.

Proceder à análise da feição simbólica do tema 'viagem' em Mário de Carvalho conduz-nos a uma série de ponderaçóes sobre os componentes estéticos da narrativa fantástica, tanto a passada como a atual, sobretudo por estarmos diante de uma obra literária que estabelece um jogo intertextual com textos canônicos diversos, como veremos. O primeiro elemento que merece atenção é a figuração do protagonista, que propiciará pistas tanto sobre o aspecto simbólico da viagem, quanto de outros componentes do texto fantástico, como a composição do espaço, do tempo, do transporte e do objetivo que se espera alcançar.

De acordo com a perspectiva analítica que desenvolveremos sobre a viagem fantástica, iniciaremos pelas rubricas Exórdios, Países e Exemplos.

Como o próprio nome do capítulo indica, os temas tratados em Exórdios ${ }^{3}$ são o começo de uma urdidura narrativa que é ampliada nas rubricas seguintes. Sob a ótica dos gêneros, o exórdio possibilita uma projeção de informação, revelando "um determinado horizonte de expectativas pragmáticas que suportam a concretização de determinadas configuraçóes temáticas e semânticas ou ainda a sua derrogação total ou parcial". ${ }^{4}$ Dessa forma, os temas sobre o 'outro' como fuga de uma rotina, a busca de 'deus', a guerra e a configuração de terras diferentes, ou do impulso que mantém o homem vivo, aqui apenas sugeridos, são explorados de forma mais ampla nos textos seguintes.

Dos contos incluídos nos Exórdios, há dois que particularmente interessam ao tema que nos propomos desenvolver, a viagem extraordinária calcada nos modelos antigos $(13,19)$. Os personagens centrais não são nomeados, porque o que importa nessas narrativas é o caráter "moralizante"

3 Gaffiot, F., Dictionnarie Illustré Latin-Francais. Paris: Librairie Hachette, s.u. Exordium advém de exordiri "começar a tecer". Relacionado à língua significa "início de um discurso"; em sentido amplo - "começo, princípio, origem”. Na aplicação literária, aponta para a definição básica de uma trama, que depois se preenche, retoca e desenvolve.

4 Diogo, A. A. L. (1997), Exórdio. In: Biblos-Enciclopédia Verbo das Literaturas de Lingua Portuguesa. Lisboa, São Paulo, Verbo: 446-447, 446. 
da fábula associado à "busca" realizada pelo sujeito, anônimo e universal, e "o que" ele encontrará ao final da viagem. O primeiro texto, extremamente curto, funciona como uma espécie de preâmbulo a condensar, em traços abrangentes, o modelo em causa. Não há nele indicação do transporte utilizado, nem do tempo que se gastou na viagem; sabemos apenas que, movido pelo desejo, "um homem quis ir até ao fim do mundo e foi" (13). Primeiramente, há que se atentar para o personagem que se aventura numa busca do "fim do universo": identificado genericamente como "um homem", poderíamos afirmar que ele representa o Homem em sua busca incessante, quer seja através da literatura fantástica ou através da ciência, como da simples imaginaçáo, pelo conhecimento do que seria esse outro 'lugar', tão extremo e distante da realidade conhecida, e que seres possivelmente nele habitariam. Identificado, num anonimato global, esse sujeito, impóe-se de imediato outra questão: o que motiva a viagem. Nesse pequeno conto, o personagem "quer" ir ao fim do mundo, fator que o diferencia daqueles personagens dos primeiros contos que são lançados, sem consulta prévia, a uma aventura fantástica da qual náo querem participar. Acrescido à vontade, o simples registro de que ele 'foi', leva-nos a uma dúvida inevitável e para a qual não há uma resposta única: o protagonista foi realmente ou simplesmente viajou através da imaginação? Mas seja qual for o modo de concretização desse projeto humano, apesar de extremo, ele é mesmo assim acessível à determinação do Homem.

Executada a viagem, a paisagem do fim do mundo é revelada em termos vagos, mas expressivos daquilo que, sem se conhecer, se imagina grandioso, numa dimensão que se sente universal: "era uma grande falésia que dava para um abismo" (13). De novo a terminologia utilizada é extremamente ambígua, pois após as rochas altas (que em uma falésia comum dão para o mar) havia um abismo, palavra sinônima de voragem, precipício profundo ou em sentido figurado 'o que não é compreensível', 'o que é misterioso', ou ainda, simbolicamente, "aquilo que é sem fundo, o mundo das profundezas ou das alturas indefinidas". 5 Diante dessa visão de algo que o confunde e o desafia, uma dúvida assalta o homem: "Mas onde é que fica mesmo o fim do mundo? Aqui ou lá em baixo?" (13). De fato, o homem pergunta-se sobre o local em que ele mesmo está: início ou fim do mundo? $\mathrm{O}$ advérbio 'aqui' representa para o aventureiro o que é conhecido, o que é real, palpável, ao contrário de 'lá', que se afigura como incompreensível e que, por isso, pode gerar medo e desconfiança. Pensamos quase sempre

\footnotetext{
5 Chevalier, J., Gheerbrandt, A. (1982), Dicionário dos Simbolos. Paris, Teorema, s.u.
} 
que a posição de estar "aqui" ou de estar "lá" é uma disposição espacial antagônica simples, mas para o personagem essa relação produz mais dúvidas que certezas, porque ele encontra-se em um lugar fronteiriço. Esse entre-lugar produz no personagem a impressão de desorientação, ou distúrbio de direção, porque é, antes de tudo, um locus de deslocamento exploratório ininterrupto que oscila entre "o aqui e lá, de todos os lados, (...) para lá e para cá, para frente e para trás”. ${ }^{6}$

Também em busca de algo que lhe é caro, ou em fuga do que o martiriza, viaja o herói de um outro conto (19), por um meio que o narrador deixa oculto. Pela mão do acaso, ou de um impulso inconsciente, um velho mercenário chegou a uma cidade não nomeada, descrito como um homem "todo couraçado de armas". De início, o fato de o protagonista chegar coberto de armas provoca a impressão de que ele estaria em busca da guerra; mas o motivo da viagem torna-se claro: ao viajante agrada, pelo contrário, um sítio em que possa viver sem guerras, em paz; traduzindo em outras palavras, o mercenário procura despir uma identidade que o deprime tão somente pelo seu contrário. Assim, logo ao entrar, embora recebido de forma hospitaleira, foi detido pelos vereadores que o advertiram da proibição de andar armado na cidade. O homem pergunta o porquê dessa imposição para vir a saber que a cidade é da paz. Feliz, o mercenário afirma: "Enfim, tenho o que quero. Vou trabalhar de ferreiro" (19). O mesmo material, o ferro, passa a acumular duas conotaçóes: a guerra, simbolizada pelas armas, e a paz, expressa no exercício de uma profissão artesanal; ou seja, o homem quis mudar de vida sem perder a própria natureza. No entanto, quando tenta tirar as partes da armadura e deixar o escudo, "deu por que estavam embutidos na carne, como crostas, debaixo das quais havia um pulsar de carne viva" (19). Quando o viu, um vereador disse: "esse levou a guerra táo a sério que já nem sabe querer a paz" (19). Tema, de resto, sempre atual sobre que o narrador leva-nos a refletir: as guerras que perduram sem que se saiba realmente o porquê, ou melhor, que a história da Humanidade é a crônica de uma sucessão de guerras.

O personagem, ao aventurar-se em busca da paz, fez uma tentativa frustrada, porque a guerra havia tomado toda sua essência humana. A ima-

6 Cf. Bhabha, H. K. (1998), O local da cultura. Belo Horizonte, Editora UFMG: 19. Tomamos de empréstimo as reflexóes de Bhabha sobre os Locais da Cultura: a cultura se localiza no "entre-lugar'. A epígrafe de seu livro é elucidativa a este respeito. "Uma fronteira não é o ponto onde algo termina, mas, como os gregos reconheceram, a fronteira é o ponto a partir do qual algo começa a se fazer presente". 
gem do homem couraçado demonstra uma espécie de metamorfose pela qual passou o protagonista, pois havia se transformado, sem retorno, em uma 'máquina bélica'. Este é precisamente o mesmo rumo de pensamento da comédia Aves, de Aristófanes. Alguém parte à procura de um outro mundo, que não sabe qual é nem onde fica, porque o seu lhe desagrada (curiosamente, porque quer também trocar a guerra pela paz). Encontra-o no mundo ideal das aves onde não há dinheiro, nem tribunais, nem tudo aquilo de que fugia. Mas o herói ateniense também não é capaz de querer a paz e acaba contaminando 'a cidade das aves' com os males que não conseguia afastar, a tal ponto deles estava contaminado. Mário de Carvalho não vai tão longe, preserva a identidade pacífica dessa outra cidade, pela simples expulsão de quem nela não tem lugar.

Os dois personagens anônimos e solitários, destes contos de Exórdios, através de uma viagem, aproximam-se do que procuram, de forma que esse novo conhecimento ou lugar especial se constitui como um auto-aprendizado: no primeiro caso, o homem defronta-se com os limites da realidade que pretende ultrapassar, na busca de outra 'verdade' que tem a dimensão do universal; no segundo, o personagem inicia um processo que o leva ao conhecimento de si mesmo, e esse conhecimento pode pôr abaixo suas ilusōes de ultrapassar a sua própria condição. Aqui não há uma salvação do sujeito, e sim a constataçáo de que, respondidas as interrogaçóes ou buscas que o mantinham vivo, permaneceu como no estágio anterior. Falta realizar um movimento de 'ascensão' que de fato o liberte e o redima da mediocridade humana.

A rubrica Paises contém um grupo de seis textos, que, como o próprio nome indica, contam histórias de povos e países criados pela imaginação do autor e que, apesar de serem criaçôes ficcionais, relacionam-se a alguns aspectos históricos e a alguns temas literários específicos.

Em dois contos $(23,26)$, os povos são conduzidos pelo rei por uma longa viagem ou travessia. Assim o tema do escapismo parte do individual para o coletivo, numa flutuação a que a tradição grega tinha dado execução. O primeiro rei era movido simplesmente pelo tédio que o tomava; por isso ordenou uma mobilização geral para invadir a Índia, terra longínqua e desconhecida, mas promissora (23). À frente do exército, obteve muitas conquistas em longos anos de guerra, conseguindo inclusive tomar a Índia, uma espécie de nova Tróia. "Mas quando o rei quis regressar, com o seu exército, já ninguém se lembrava onde ficava o seu país. Tinham-no perdido" (23). Embora não possamos identificar integralmente as relaçóes intertextuais que o texto estabelece, parece haver "ecos" da Odisseia no 
conto: como na épica grega, o rei, após anos de ausência e guerra, apesar da glória alcançada através da empreitada, quer retornar ao seu país assim como Ulisses, mas isso é impossível, tornando o rei e seus companheiros solitários, ou melhor, estrangeiros e apátridas.

Invertendo os passos épicos, o conto não nomeia o povo ou o rei, não comenta as etapas da viagem, não insere deuses que agem a favor ou contra o herói, não comenta a recepção dos estrangeiros na Índia; enfatiza apenas o desejo do retorno, depois das glórias da conquista, a um lugar e a uma vida normal, mesmo se entediante ou rotineira. Além desse desejo de retorno, assemelham-se os textos pelo fato de o rei ter-se perdido como Ulisses esteve. Mas a Ítaca que se tornou, para o seu senhor, o desafio de uma nova aventura, a do reencontro consigo mesmo, parece vedada a um novo viajante, para quem a falta de regresso ecoa como uma condenação.

O conto pode ser entendido, ainda, como uma representaçáo da expansão marítima portuguesa, especialmente a empreendida por Vasco da Gama em direção à Índia e, assim, relaciona-se com Os Lusíadas, de Camóes, a voz de uma 'odisséia' lusitana. Embora o país invasor não seja identificado, sua ligação simbólica com Portugal parece evidente, na medida em que a narrativa demonstra passos parecidos com os da expedição portuguesa: enquanto a viagem avança e as terras são conquistadas, vão-se perdendo homens, ou porque morreram durante a viagem ou porque resolveram permanecer nos sítios em que aportaram. A expressão que fecha o texto "Tinham-no perdido" pode indicar também a perda do poderio português após as expansóes marítimas, ou que os esforços para gerir ou manter as colônias tivessem impedido os governantes de pensarem em seu próprio país, o que o fez, metaforicamente, cair no esquecimento. O que parece claro é a alusão a um Portugal que após a saga marítima não voltou, de fato, a ser o mesmo, tal como previra o Velho do Restelo, em $O s$ Lusiadas (cf. 4. 94-104).

O rei do conto seguinte tinha, para sua viagem, uma outra ambição: levava seu povo faminto e desesperado para "uma ilha fértil e verdejante que conhecia" (26). Não propriamente para escapar ao tédio, mas às dificuldades e à mediocridade, o soberano procurava soluçóes, sonhara com um troféu que esperava conquistar à distância. Tal como ocorre em algumas passagens da Odisseia, a imagem da ilha paradisíaca apresenta-se como um refúgio ideal e capaz de salvar um povo (ou um herói) da morte,

7 Camões, L. (1979), Os Lusiadas. Prefácio de Hernâni Cidade. São Paulo, Abril Cultural. 
oferecendo-lhe uma etapa de delícias e refrigério. De forma diversa dos outros contos que analisamos, o narrador informa o percurso que irá ser feito e 'como' iráo fazê-lo. Para alcançar o destino, "havia que atravessar a pé enxuto uma língua de areia de muitas milhas, aproveitando a maré baixa" (26) e o percurso devia ser feito em apenas uma hora, tempo que o refluxo da água permitia. Mesmo tendo que atravessar o mar para alcançar o destino, a escolha do meio de transporte é diferente das outras formas habituais que se utilizam, como um navio, uma jangada, a nado, levado pelas ondas: para atravessar o mar, teriam que caminhar. Há nesse desafio a sensação de um confronto, despojado de meios, em que o homem se depara, de mãos vazias, com a grandeza do seu sonho.

$\mathrm{O}$ conto possivelmente remete à passagem bíblica em que Moisés leva o povo do Egito para a terra prometida. Diante do mar Vermelho, o profeta toca com o cajado as ondas que se abrem para o povo passar, mas fecha a seguir, fazendo com que os perseguidores morram afogados. ${ }^{8}$ No conto de Países, o inimigo náo é um exército e sim a fome que fez com que o povo se demorasse recolhendo os mariscos. Assim como Ulisses e Moisés, o rei brigou e exortou o povo para que se mantivesse no caminho, mas de nada adiantou, porque os companheiros não largavam os mariscos, que comiam ali mesmo, crus. Logo veio a maré e "os quinhentos e setenta e sete membros daquela caravana, que formavam todo o povo, pereceram afogados" (26).

O rei age como um herói a quem foi confiada a salvaçáo de todo um povo, seus companheiros de viagem, e como ocorre com Ulisses, a responsabilidade pela morte dos companheiros não é sua, mas da imprudência dos outros. De resto, o tema da fome que levou os companheiros de Ulisses à desobediência ao seu comandante e à morte recorda o episódio da ilha de Hipérion (Od. 12. 340-425). O fato é que o rei conseguiu chegar "sozinho à ilha e aí ficou rei sem povo" (26). O isolamento para que caminha confirma a posição inicial dessa análise sobre a solidão do aventureiro. Solidão que exprime, antes de mais, a própria qualidade de ser herói, de possuir a grandeza para enfrentar dificuldades, de não se deixar vencer por carências e limitaçōes de natureza humana, em nome de um ideal superior. Esse é o segredo de glória que se consagra na solidão de um herói bem sucedido: a arte de conquistar a excelência e o preço a pagar.

Sugestivo é também, no seu simbolismo lacônico e baseado numa expressiva simetria de palavras, o conto (25) em que um homem veio do

8 Almeida, J. F. (1997), Bíblia Sagrada. Rio de Janeiro, Fecomex (Ed. Revisada e corrigida). Ex., 14.21-30. 
país hiperbóreo e disse: "Tivesse eu uma alavanca e levantava o mundo!" Veio outro e diz: "Tivesse eu um mundo e levantava alavancas." E "aqui começou a mais áspera desde sempre guerra religiosa”. Não se pode deixar de mencionar que a expressão utilizada pelo protagonista é uma repetição da famosa frase de Arquimedes dirigida ao rei Hierão: "Dê-me um ponto de apoio e moverei a Terra." (Dij87, p. 15). ${ }^{9}$ Tal frase foi proferida pelo matemático grego quando conseguiu desempenhar uma difícil empreitada solicitada pelo rei Hierão: jogar ao mar uma pesada embarcação deslocando-a só com uma combinação de polias e alavancas. ${ }^{10}$

Outra questão para a qual se deve atentar é que o país de onde vieram parece indicar um lugar isento de todo mal, arredado da civilizaçáo, 'branco' no seu desenho. O 'país dos hiperbóreos' contém, em Mário de Carvalho, o duplo sentido clássico, sacro e geográfico. $\mathrm{O}$ nome advém de uma possível localizaçấo, "para além dos lugares de onde procedia o vento Bóreas ou do Norte", ${ }^{11}$ ou seja, para além das fronteiras do mundo conhecido, 'branco' também em termos civilizacionais.

Heródoto referiu-se a esse povo, embora não admitisse sua existência. Sobre eles, afirma o autor de Halicarnasso que, “(...) nem os Citas nem nenhum dos outros povos que habitam na zona dão a mais pequena informação, a não ser os Issédones. Mas, julgo eu, nem mesmo estes têm nada a dizer, senáo também os Citas o diriam, do mesmo modo que falam de homens com um só olho" (4. 32) ${ }^{12}$. Se para o historiador a inexistência desse povo é evidente, na literatura grega são abundantes as referências a esse país como um lugar destinado aos bem aventurados. A propósito das referências aos Hiperbóreos na literatura, o próprio Heródoto dá-nos pistas dos autores em que ocorrem: "é Hesíodo quem fala dos Hiperbóreos, como também Homero nos Epígonos, se é realmente Homero autor dessa epopéia” (4. 32). $\mathrm{Na}$ concepçáo sacra veiculada pela literatura, o país dos Hiperbóreos é um

9 Dijksterhuis, E. J. (1987), Archimedes. Princeton University Press, Princeton. Translated by C. Dikshoorn. Apud Assis, A. K. T. (2008), Arquimedes, o centro de gravidade e a lei da alavanca. Montreal, Canadá: Apeiron Montral: 16.

10 Assis 2008: 16.

11 Errandonea, I. (1954), Diccionario del mundo clásico. Barcelona, Editorial Labor, s.u.

12 Segundo Heródoto (4. 33), o povo que mais se refere aos Hiperbóreos são os Délios, que afirmavam serem os Hiperbóreos quem enviava à Cítia ofertas sacras embrulhadas em palha de trigo. "A partir da Cítia, cada povo as recebia dos seus vizinhos e as fazia circular rumo a ocidente, tão longe quanto a costa adriática (...)". Tradução de Silva, M. F., Guerreiro, C. A. (2000), Heródoto, Histórias. IV. Lisboa, Ediçóes 70. 
local destinado aos eleitos, de onde o homem sai 'branco', como de uma espécie de ato criador. Píndaro (Pítica 10. 29-46) descreve-os como um país idealizado e maravilhoso relacionado a Apolo, para o qual não há caminho nem de barco nem a pé. Para os Gregos, os homens escolhidos pelos deuses iam para os Hiperbóreos gozar uma felicidade só possível no além, longe das doenças e livres da velhice. ${ }^{13}$

Prevalece, nesse conto, a idéia de que estes homens saíram desse (não) lugar "brancos", isentos de uma contaminação sociocultural (ou técnica). Uma leitura possível para o conto seria a de que com uma ferramenta mecânica, a alavanca, aqui emblema da técnica, o homem julga-se capaz de levantar o mundo, de dominá-lo até ao infinito. Mas se em vez da técnica, pensa o segundo personagem, possuísse o infinito (o espírito), teria o poder absoluto sobre todas as alavancas; ou seja, não é o homem que depende da técnica para atingir o infinito; é o próprio talento humano que deve conduzir e dominar a técnica. Sob esta ótica, há um detalhe importante além da pura simetria das palavras: ao cruzar o singular e o plural de alavanca, insinua-se a idéia de que o espírito é capaz de multiplicar a técnica e de fato dominar a descoberta e a capacidade mecânica. A guerra religiosa "mais áspera desde sempre" (25), iniciada após esse ambíguo diálogo, poderá estar relacionada com a maneira como cada um concebe a realidade que o cerca: as civilizações, ao longo da história da humanidade, distanciam-se exatamente porque algumas privilegiam a técnica e outras valorizam o espírito e, na maioria das vezes, são incapazes de aceitar as diferenças.

Do capítulo Exemplos, destaca-se ainda a viagem de "Luizardo, o auto-emparedador loucamente aventureiro" (57). A escolha vocabular para o nome do personagem, Luizardo (que sugere Felizardo, o que é feliz porque encontra a 'luz'), e para o nome da cidade em que mora, Sylampus, caracteriza o protagonista como alguém iluminado ou destinado à luz.

Cabe salientar a relevante oposição entre physis e nomos que aparentemente envolve o personagem. Segundo Kerferd, "o termo physis é traduzido por natureza", "natureza do homem" e nomos seria a 'lei', a 'convençáo'

13 Para uma discussão sobre concepçôes de felicidade após a morte, veja-se Rocha Pereira, M. H. (1955), Concep̧̧óes Helénicas de felicidade no além: de Homero a Platão. Coimbra, Marânus.

14 Vide Kerferd, G. B. (2003), O movimento sofista. Tradução de Margarida Oliva. São Paulo, Ediçóes Loyola: 189. Era também utilizado para designar "a totalidade da realidade", mas, em todos os casos, "o termo envolvia, pelo menos por implicação, um contraste entre as características apropriadas a uma coisa como tal, que ela possuía por direito, ou por sua própria vontade, por um lado, e características adquiridas ou impostas". 
ou o 'costume'. ${ }^{15}$ Como lei, nomos significa "norma legalmente prescrita, e (...) como convenção, é norma prescrita por convenção".

Já no início do conto percebe-se a contradição irônica com que o narrador define o personagem do dia-a-dia; ele é um auto-emparedador, ${ }^{16} \mathrm{o}$ que significa que "empareda", "confina" a si mesmo; e é loucamente aventureiro, algo paradoxal para quem quer apenas fazer paredes, sugestáo de alguém cuja physis (natureza) lhe aconselha ir além e procurar a luz, mas cujo nomos (norma) o prende entre paredes. ${ }^{17}$ Mas Luizardo não entendia que para exercer essa profissão tinha que ser um "homem sedentário ou bem medido nos passos a dar" (57), imposição de um nomos, uma regra social de vida, que difere da natureza. O problema é que nasceu em Sylampus, local em que não havia pedras, nem argila, nem cal, e todas as casas construídas eram de palha. E "um auto-emparedador, por mais imaginoso que seja não pode exercer-se numa terra de edifícios de palha" (57). Entáo, um dia, o rapaz pegou um mapa e de olhos fechados apontou para o acaso. Havia apontado para o país Hiperbóreo, para onde "se apressou a navegar na próxima carreira” (57). O fato de Luizardo navegar até lá teria um sentido figurado, já que como mostramos anteriormente, não há caminhos que levem a esse lugar. Novamente o país dos Hiperbóreos aparece em Fabulário, náo como ponto de partida, mas como destino do personagem, que apesar de ser descrito na literatura como um lugar especial, destinado a poucos, que podem usufruir de uma vida feliz e agradável, ${ }^{18}$ simboliza a morte (simbólica e real) para o personagem. Para decepção de Luizardo, nesse país não havia casas de tijolos ou pedras, e sim de blocos de gelo. Decidiu emparedar com gelo, cortando-o com uma faca. "Morreu congelado, já com dois palmos de parede prontos" (57). Ao que parece, o conto

15 Ibidem 2003: 191. De acordo com o autor, nomos e os termos "cognatos, em grego, são sempre prescritivos e normativos, nunca meramente descritivos - eles dão algum tipo de direção ou ordem que afeta o comportamento e as atividades de pessoas e coisas".

16 Cf. Arnaut, A. P. (2001), "Donas e donzelas n’a Demanda do Santo Graal", Santa Barbara Portuguese Studes. Califórnia, n. 5, 29-71. Na Demanda do Santo Graal, há personagens femininas chamadas emparedadas, que se recolhiam voluntariamente em uma estreita cela (para expiar culpas ou obter recompensas pela inocência castigada), cuja porta era fechada com cal. Esse caminho só era aberto para levar a mulher morta à sepultura. Eram as emparedadas confessoras ou conselheiras espirituais dos cavaleiros que buscavam o Santo Graal.

17 Para uma análise mais ampla dos termos, cf. Guthrie, W. K. C. (1976), Les Sophistes. Paris, Payot.

18 Rocha Pereira 1955: 38. 
valoriza a idéia de inadequação de sua physis às normas sociais, porque de fato sua natureza não mudou até a morte.

Em Fabulário, o retrato do protagonista e o objetivo da viagem, agora desenvolvido com o desenho do 'outro', não possuem uma feição única. Envolta pela fantasia, a função da aventura é a de propiciar ao personagem (e ao próprio Homem) uma reflexão sobre o papel que desempenha no universo que o circunda; o tema 'viagem' amplia-se, como potencialidade de encontro do sujeito consigo mesmo ou com o que lhe é estranho.

O herói pode partir sozinho em busca de suas aspiraçóes (14, 15, 16, 17); mas na maioria das vezes, sobretudo naqueles contos sob a rubrica Deambulaçóes de Cat' e Gat', é comum em cena um par viajante, o que possibilita a interlocução de idéias e as divagaçóes muito freqüentes sobre a nova ordem que encontram. Esta é uma técnica já presente em Aves, de Aristófanes, com Pistetero e Evélpides. Porém, ao contrário do que ocorre na comédia grega, ${ }^{19}$ em que um dos elementos do par contribui para a caracterização do outro ou tem um poder de comando superior, a função do companheiro em Fabulário é a de possibilitar uma discussão sobre uma ordem social diversa ou um evento ocorrido; esta reflexão encerra sempre uma "moralidade", ou teorizaçáo sobre as linhas de força de uma cultura. Os componentes do par viajante quase sempre têm, neste caso, uma posição de igualdade um em relação ao outro e nenhum possui uma autoridade ou uma "verdade" absoluta sobre determinado assunto.

As curtas narrativas sobre o motivo do 'outro' e da 'viagem' não se detêm em descriçóes pormenorizadas do trajeto percorrido ou dos traços psicológicos dos personagens, mas nem por isso prescindem da ponderação sobre a cultura, a sociedade e a vicissitude humana. Das variadas motivaçóes que levam os personagens a saírem de sua rotina, salientamos a busca voluntária de uma solução ou objetivo $(16,17)$, ou mesmo uma fuga desse sujeito (18), por um espaço ou nomos no qual sua alteridade seja aceita ou onde o encontro com seus semelhantes seja possível. Assim, essa viagem que o personagem realiza por vontade própria, às vezes é determinante para que escape da morte ou de um destino que lhe desagrada, pois ele sofre uma rejeição por parte da sociedade (18). Pode ser também objetivo da jornada a simples deambulaçáo sem destino, ao acaso, na qual os personagens não possuem um propósito previamente definido, pois o que lhes guia é a curiosidade de conhecer culturas e locais diferentes, como o fazem Cat' e Gat'; este é precisamente o mesmo motivo que conduz o

\footnotetext{
19 Cf. Aves 3 sqq.
} 
narrador de A História Verídica de Luciano de Samósata. Entretanto, esse passeio voluntário e sem destino, fadado sempre a um inevitável encontro com diferentes sociedades e culturas ímpares, em algumas ocasióes, conduz os aventureiros casualmente a destinos imprevistos, por uma ação da natureza, como um naufrágio (77), por exemplo, ou simplesmente porque se perderam no caminho (81).

Obviamente, que o acaso ou a vontade de ir além podem determinar os meios pelos quais se fará o percurso. Quase sempre precedidos de expressóes imprecisas de tempo como "Certa vez" (73) e "Era uma vez" (67), que introduzem igualmente as fábulas ou os contos de fadas, o itinerário e as distâncias percorridas manifestam uma constante indefiniçáo; assim as fórmulas estilísticas com que são expressos primam pela imprecisão e laconismo, na medida em que uma viagem fantástica ou simbólica não carece necessariamente de medidas concretas, como as estabelecidas por Luciano $^{20}$. Da mesma forma que ocorre em Aves, a distância é apenas sugerida nos contos como um "andar à deriva" (Aves 3-4), pois é natural que se (in)defina a extensão percorrida pelo herói com um simples "andou de terra em terra" (17), "fugiram (...) e instalaram-se" (18), "cortar caminho (...) num bote" (77), "calcorrearam montes e vales" (85) ou "iam andando, andando" (89), ${ }^{21}$ como uma forma de diluição de espaço e tempo, que permita uma identificação entre o mundo da fantasia e o mundo atual, sempre objeto de apreciação por parte do autor.

Percorrida a distância que separa o viajante de seu objetivo, avaliemos as primeiras impressóes sentidas e a paisagem (ou cultura) a que tem acesso no mundo diferente com que se depara. Nessas narrativas fantásticas, o personagem, às vezes, não se surpreende com o que encontra, porque é justamente o extraordinário que procura, como um país em que todos possuam quatro braços (17), por exemplo; o que não impede uma decepção ao se encontrar a terra para a qual quis viajar, porque apesar de realmente existir tal lugar, paradoxalmente, ele não atende as expectativas do personagem (17). Por outro lado, o efeito causado pela imagem da terra estranha e dos costumes que nela se praticam pode provocar uma surpresa aos visitantes que lá chegam por acaso, como ocorre com o encontro dos heróis com o excesso de estátuas que representavam gente humilde na ilha de Fezro (77); um simples enfado (e falta de compreensão) ante a monotonia e a pobreza deprimente de uma aldeia em que uma família constrói uma estrada sobre

\footnotetext{
20 Cf. História Verdadeira I.10.

21 Cf. a similaridade da situação em Aves 1-4.
} 
um pântano (85); ou, então, o receio e a inquietude sentidos frente a uma paisagem desconhecida e aparentemente ameaçadora (89).

Entretanto, a viagem não é o único meio pelo qual se pode ter acesso ao horizonte ou retrato do 'outro': em alguns contos (cf. 14, 15, 67), a alteridade é desenhada e acentuada através de uma aproximação paradoxal, no mesmo espaço, ou anacrônica, entre um ser aparentemente comum frente a outro diferente de seu interlocutor. A descoberta de um mundo antes inacessível e estranho por vezes é desencadeada após uma dissolução de fronteiras (real ou simbólica) que antes escondia ou impossibilitava-lhe o acesso. As fissuras, inesperadamente abertas na rotina do sujeito, ou em uma hermética muralha que o bloqueia, podem ser um canal que possibilita a uma sociedade um contato não com um mundo fantástico, mas sim com a physis a que de fato pertence e da qual havia se afastado em função de um "automatismo técnico" (27). Por outro lado, através da tradição antagônica entre luz e treva como emblema de conhecimento/falta de conhecimento, o encontro com a luz por parte de um sujeito pode ser a condiçáo essencial para que se tenha acesso a um mundo novo ou para que uma nova ordem social e cultural seja descoberta (28).

Através de uma posição diametralmente oposta do conflito existente entre Gregos e Bárbaros que ocorreu na tradição clássica, o tema geral desses contos é o encontro pacífico, ainda que não isento de incompreensão, de sujeitos que se interrogam em vários tons sobre um modelo mais satisfatório de sociedade, sobre o papel do coletivo, sobre o que é o conhecimento e a realidade, e, principalmente, sobre a identidade ou alteridade. Sem que Mário de Carvalho exclua os elementos com que a tradição desenhava essa hostilidade latente entre diferentes comunidades, como em obediência a um passado literário e cultural, o desfecho é, porém, o inverso da convencional tensão. Essa idéia de uma convivência pacífica entre aqueles que chegam e o 'outro' da fantasia exprime-se, primeiramente, pela forma como os viajantes são recebidos e ajudados quando estáo em perigo, obtendo uma boa acolhida $(77,81)$ na terra a que chegam, bem como pela alegria demonstrada pelos xenoi com a chegada dos visitantes (89). Assim, a caverna situada "a meio dum campo de pedras soltas, grandes, irregulares, rugosas, ameaçadoras" (89), por exemplo, de forma inversa de $O$ Ciclope e Ifigênia entre os Tauros, em que o cenário contribui para a caracterização de um ambiente hostil, não apresenta qualquer risco. A paisagem aparentemente perigosa do conto $A$ Luz é desmentida quando Cat' e Gat' entram na caverna e são bem recebidos pelos moradores (89), que respeitam a vida e a integridade física do hóspede. $\mathrm{O}$ fato de os visitados não possuírem um plano urbanístico 
e de morarem em uma caverna como Polifemo (Eurípides, Ciclope 115) indica uma espécie de primitivismo e isolamento, mas não um perigo aos visitantes. Estilisticamente, a manifestação de respeito pelo hóspede revela-se também pela liberdade e tranqüilidade com que o viajante percorre a regiáo desconhecida ou se dirige aos moradores do lugar com perguntas que visam a permuta de conhecimento e o cruzamento de informaçóes sobre os nomoi diferentes $(77,86,89-89,105)$. Logo, há uma aceitação da diferença que se demonstra através de expressóes repetidas como "ouviram polidamente" (78) ou "não ficaram surpreendidos" (90).

Embora os textos sejam marcados por reflexóes profundas, estas são feitas com um tom irônico (e às vezes cômico), diferentes do que ocorre na tragédia. Nem todos os elementos de que se servem os autores clássicos para definir o 'outro' estão presentes nos textos de Mário de Carvalho que analisamos, como a língua, por exemplo, um fator básico onde a idéia da diferença, traduzida na dicotomia Grego/Bárbaro, teve, como vimos, a sua origem.

Discorrer sobre o retrato físico do personagem em Fabulário implica relacionar o sujeito do mundo ficcional com o 'outro' grotesco e o insólito. Diferentemente do que ocorre nas narrativas de Heródoto ${ }^{22}$ e na tragédia esquiliana Persas ${ }^{23}$ - em que o retrato do 'outro' é mostrado não só através da descrição física, mas, sobretudo, pelo tipo de vestimenta ou adorno utilizado, ou por pormenores de etiqueta, como fatores que distinguem diferentes núcleos culturais, em si mesmos coesos -, em Mário de Carvalho esse sujeito pode não ser o 'outro' em relação a uma comunidade padrão harmônica, e sim um sujeito de exceçáo dentro da comunidade a que pertence. Nesse sentido, o 'outro' é visto de forma individualizada e, principalmente, simbólica de uma insatisfação ou de uma desadaptação do sujeito da diferença ao próprio nomos, expressa como uma reação profunda, natural e física. Dessa forma, o movimento de diferença, no plano coletivo, projeta-se de dentro para fora e não o contrário.

Entretanto, a construção ficcional desse ser diferente é estabelecida a partir de critérios do nosso próprio mundo, como o faz Luciano em História Verdadeira. Os seres monstruosos e estranhos que construiu deformam sempre um pormenor ou aspecto de seu ambiente ou cultura; as mulheres-videiras, por exemplo, embora fisionomicamente híbridas, são

22 Cf. Heródoto 1. 215 (sobre a descrição dos Masságetas) e 3.17 (sobre a descrição física dos Etíopes).

23 Cf. 81-182. 
compostas de elementos que Luciano conhecia, como uma parte do corpo feminino e a videira ( $H V$ I.8), apenas combinados de forma estranha. Também representativos desse tipo de construçáo fantasiosa, que tem como base um elemento tradicional deformado através de uma imitação cômica, são os componentes do fantástico exército lunar de Endímion, como as Hortaliças-Voadoras ou os Lançadores-de-Bagos-de-Milho (I. 13). Nessa mesma perspectiva de criação, Mário de Carvalho constrói a diferença de seus personagens acrescentando ou diminuindo membros ao modelo humano conhecido, simbolizando uma capacidade de fazer ou de agir mais poderosa do que a comum à espera de encontrar realizaçáo. Segundo Melero Bellido, nossa mente, diante de situaçóes novas, só se guia através da utilização da analogia com o que é previamente conhecido. A maneira de associar o ignorado e "o exótico mediante o mais conhecido ou cotidiano, segue alguns códigos que têm a ver com a tradução, com o que poderíamos chamar de uma gramática do fantástico, incluindo nessa categoria o exótico, o imaginário e o utópico". ${ }^{24}$

É este o teor do conto do homem que tinha duas pernas, mas que usava apenas uma para economizar energia (14); do cauteleiro que só tinha um braço e por isso se acautelava dos males sofridos pelos que tinham dois (15); do conto do menino que nasceu com quatro braços, em que todos reconheciam potenciais inauditos, ou que lhes permitiam, com exclusividade, obter tarefas particularmente exigentes (16-17); e do conto do gigante ${ }^{25}$ que imobiliza um braço, porque tinha demasiada força e fartura (67-69). Em todas as comunidades em que esses sujeitos vivem, reconhece-se seu potencial de energia superior; mas há uma incomunicabilidade e uma incompreensão perante a diferença, que se exprimem por perguntas surpreendidas, como a que faz o vizinho do homem que usava só uma perna: "assim não se cansa mais?" O homem responde: "Não posso" (14), porque seu objetivo é poupar e não gastar mais energia cansando-se, mas o diálogo traduz uma impossibilidade de compreensão da diferença. Essa é uma tensão também

24 Melero Bellido, A. (2004), "La lengua de la utopia”. In: López Eire, A., Guerrera, A. R. (Eds.). Registros Lingüisticos en las lenguas clásicas. Salamanca, Ediciones Universidad Salamanca: 150 .

25 O desenho do 'outro' como um monstro mítico ganha expressão nesse conto com um gigante "que vivia num altíssimo palácio, a meio da pradaria em que os ventos pararam" (67). Se na Odisseia e no drama satírico, o gigante Polifemo representa uma ameaça para quem aporta em sua ilha, em Mário de Carvalho, o gigante não representa um perigo para aqueles que o conheciam. Na verdade, o gigante é diferente de Polifemo (Cf. Eurípides, Ciclope 121, 123-124), pois, além de conhecer o vinho, cultivava hortas, vinhas e pomares. 
presente em relação ao cauteleiro que, diante de uma epidemia na cidade que provocava dor e inchaço nas "mãos dextras das pessoas" (15), ria muito, dizendo: "só eu não sinto nada" (15). Ironicamente sua mulher afirma que está isento da dor porque não possui "mão direita" (15), observação onde se patenteia a constante disparidade de leitura perante o estranho: "Sua parva... não entende nada" (15); de fato lhe faltava uma mão, mas a esposa não compreendia que ele tinha "potencialmente" as duas. Também surpresa, a mãe do garoto que nasceu com quatro braços, e que, por isso, se vê compelido a emigrar, pergunta-lhe para onde vai; quando o moço responde que vai para um país em que todos tenham quatro braços, a mãe contraria-lhe o projeto com a observaçáo de que "não há nenhum país desses" (16), o que demonstra uma incapacidade de imaginar a existência de algo tão diferente de seu próprio mundo.

Assim, as reaçóes das pessoas associadas a essas perguntas denunciam, no fundo, um tipo de riso trocista (ou de pura ignorância) e uma censura ao sujeito diferente, que expressam não uma aversão a esse 'outro', mas a incapacidade de lidar e compreender o que é diferente. A par do conhecido papel libertário, benéfico do riso, não se deve esquecer de seu papel coercivo, conservador e cruel sobre aquele que é seu objeto, ${ }^{26}$ pois, segundo Bergson, "o riso não pode ser absolutamente justo (...) Sua função é intimidar humilhando. Não conseguiria isso se para esse fim a natureza não tivesse deixado nos melhores homens um fundinho de maldade, ou pelo menos de malícia”. ${ }^{27}$ É com esse riso debochado, mas que expressa de fato uma falta de compreensão, que a prima do moço com quatro braços afirma que ele "na cama, hmmmmm, deve ser uma maravilha" (16). ${ }^{28} \mathrm{O}$ louvor da diferença de que é alvo o personagem por parte da família (16) assinala, através do elogio invejoso, o absurdo de sua diferença, que produz no 'ou-

26 Cf. Bergson, H. (2001), O riso: ensaio sobre a significação da comicidade. Tradução de Ivone C. Benedetti. São Paulo, Martins Fontes: 147.

27 Bergson 2001: 147.

28 Esse riso provocado pela ignorância teve expressão também na República, porque segundo Platão, no mito da caverna, aquele que havia visto o mundo exterior, em sua volta, para a caverna seria motivo de riso, porque estragara a visão com o sol, e que a tentativa de ascensão era inútil. Livro VII, 517 a e 518 a-b. Utilizamos a tradução de Rocha Pereira, M. H. $\left({ }^{10} 2007\right)$, Platão. República. Lisboa, Fundaçâo Calouste Gulbenkian. É importante ressaltar igualmente a idéia, comum em Heródoto, do significado do riso como exteriorização da ignorância; cf. 7. 103, 105. Xerxes ri quando Demarato afirma que somente mil homens lutariam contra o poderoso exército asiático. Tradução de Trejo, A. R. (1976), Heródoto. Histórias. Tomo III. México, Universidad Nacional Autónoma de México. 
tro' uma dificuldade extrema de lidar com sua alteridade frente à sociedade em que vive, o que o torna um ser solitário $(16,17,67)$.

Como os aventureiros de Aves, Pistetero e Evélpides, que partiram em busca de um mundo ideal, o moço e o homem que tinham quatro braços partiram em uma busca por seus iguais, à procura de um país em que todos tivessem também quatro braços $(16,17)$, ao encontro de um nomos compatível com sua natureza distinta, que os livrasse da solidão provocada pela diferença. É também por causa do isolamento que o gigante ensaia uma convivência com outros seres, mas a todos, numa manifestação de incapacidade visceral de convivência, perdeu por pura distração. Conclui, pois, que não serve para companhias (68), na medida em que sua tentativa de socialização (mesmo através da multiplicação de si mesmo em espelhos) fracassou (67); daí resulta uma espécie de incapacidade de viver em sociedade, que se exprime no ato de matar ou esmagar por instinto, involuntariamente, as companhias. Não podemos deixar de referir, que o exagero do tamanho do gigante é um elemento configurador do fantástico. Para Schwartz, a hipérbole (a do tipo que exagera por aumento) exprime na obra "como figura-chave que desvenda os mecanismos fantásticos da narrativa". ${ }^{29}$ De forma diversa dos outros que procuravam seus semelhantes, o gigante determinou que daí por diante viveria só. A busca pelo mundo ideal demonstra ao personagem de quatro braços (17) a exploração ou humilhação da diversidade; por onde passava, encontrou outras criaturas como ele diferentes que eram obrigadas a trabalhar em enormes torres, outras que eram mostradas em feiras e circos (17). Mas esse homem não quer se enquadrar ou submeter à norma comum, imposta por outro, e sim encontrar seu lugar no mundo, que na narrativa fantástica existe, mas não possibilita ao personagem viver sua diferença. A expressão que finaliza o pequeno texto do homem de quatro braços, "É expressamente proibido ter quatro braços" (17), encerra uma "moralidade", muito própria da fábula e que pode ser aplicada a todos os contos analisados acima: no mundo em que vivemos não há lugar para a diferença nem para se olhar para o 'outro'. Assim, o apelo dirigido ao gigante por um jovem é respondido involuntariamente com uma negativa, porque suas mãos estavam atadas para ajudar alguém (68), como uma espécie de metáfora para o sentido social e os valores da humanidade atual. Apesar de ter bons sentimentos e se preocupar com o jovem, o individualismo do gigante (e que cerca toda a sociedade atual como uma certa imposiçáo do

${ }^{29}$ Schwartz, J. (1981), Murilo Rubião: A poética do Uroboro. São Paulo, Editora Ática: 70-71. 
próprio sistema em que vivemos) impede que ele faça algo em função do próximo (69).

Logo, através do elemento fantástico, os contos retomam uma temática freqüente em Mário de Carvalho: a reflexão sobre a condição humana, sobre o sujeito "emparedado", completamente sem saída para seus conflitos com o nomos a que pertence, enfim sobre o absurdo de estar-no mundo. O homem que vive em sociedade está sempre usando "máscaras sociais" para ser aceito pelos pares, e, em função disso, o direito à alteridade vai desaparecendo. Pode-se dizer, então, que há uma crítica nesses contos à uniformização ou homogeneização humana, política, estética e cultural que ocorre nas sociedades modernas, que massificam, destroem ou rejeitam as idiossincrasias. A incomunicabilidade e a solidão dos personagens, "como conseqüências inevitáveis da existência humana, decorrentes de sua presença no mundo, são os elementos que acompanham, sem exceção, as personagens do universo" 30 ficcional de Mário de Carvalho.

Alia-se à temática da aparência do 'outro' e do conhecimento a importância da análise sobre a inversão da hierarquia social, dos valores e do sentido de areté, tema dos contos Outros tempos, outros ventos (77-79) e A tribo (81-83), de Fabulário. A imagem inicial do primeiro conto (77) é precisamente a mesma em que Ulisses, náufrago, é recebido cordialmente na corte dos Feaces (Od. 5. 450-494, 6 passim), numa retomada dos passos clássicos da narrativa de viagem. Entretanto, apesar de a hierarquia social se exprimir em Fezro por um meio convencional, que é a construção de estátuas e legendas, os valores para consegui-las são tradicionalmente contrários dos que conhecemos. Ali, as estátuas representavam somente gente humilde, cujas legendas eternizavam: "Fulano, varredor; Beltrano, coveiro; Cicrano, guarda-nocturno" (77), prática que surpreende a dupla hospedada na ilha. Os termos equivalentes aos que a épica homérica ${ }^{31}$ consagrou para a concretização dos valores elevados, como "ilustres", "os melhores", "imortalizados", "prestígio" e "fama" (77), constituem epítetos opostos à mediocridade, ${ }^{32}$ mas que aqui são dados aos anônimos. A areté para esse

30 Schwartz 1981: 82 refere-se à obra de Murilo Rubião, mas pensamos que a questão da incomunicabilidade e da solidão aplica-se, igualmente, à obra de Mário de Carvalho.

31 Alguns termos homéricos de valores guerreiros são: áristoi ("os melhores"), aristeía ("bravura"), timé ("honra"), areté ("excelência"), kléos ("glória, fama”). Veja-se Rocha Pereira, M. H. ( $\left.{ }^{10} 2006\right)$, História da Cultura Clássica, I, Lisboa, Fundação Calouste Gulbenkian: 122-143.

32 Essa espécie de endeusamento da mediocridade é representada também no romance Fantasia para dois coronéis e uma piscina, 106-108, no qual a divinização do futebol exprime a metamorfose de seus adeptos em bestas que destroem tudo que encontram pela frente. 
povo é entendida como o que é ordinário, insignificante, porque "as personagens ilustres não precisam de ser imortalizadas", afirma um vereador da ilha (77). O sistema de seleção de governadores da comunidade obedecia à mesma lógica: eram selecionados os cidadãos dispersos em meio da massa dos votados, o mais insignificante era o escolhido (78). Perguntado sobre o sistema pelos hóspedes, um homem explica que não é melhor nem pior que as outras cidades, mas ali se evitava o elitismo (78). Assim se relativizam os diferentes valores, que, mesmo se lidos inversamente, não são em si mais do que símbolo de estranheza, porque na realidade nada parecem mudar na vida concreta dos homens.

A tribo (81-83) aborda também a constituição da areté, da hierarquia social em tempo de guerra, vista como um terreno de aristeía ou de demarcação de valores. Em vez das profissóes em tempo de paz, do conto anterior, aqui é o comportamento em combate que define as hierarquias e os méritos. A tribo guerreira Bantshwanas, que deu abrigo a Cat' e Gat' quando estes estavam perdidos na savana, em conselho, discutia sobre um novo ataque de inimigos brancos; assim se estabelecem os termos com que a noção de areté da tribo se expressa pelo confronto dos valores desse povo com o dos brancos invasores. Enquanto os Bantshwanas, na guerra contra os inimigos, adquiriram fama pelos "feitos", "admiração" e "respeito" entre os povos do mundo (81), os brancos ganharam-na pela "perfídia", pela "traição", ${ }^{33}$ pela "superioridade das armas". Se no conto Outros tempos, outros ventos, as categorias sociais são estipuladas pela profissão medíocre, "o coveiro", "o varredor", "o barbeiro" (77), em $A$ tribo são dadas pelos clās, "da hiena", "do leopardo" e "do leão", que designam respectivamente esperteza, agilidade, coragem e força (82). De forma similar à tradição épica, segue-se uma descrição dos traços convencionais da areté de um guerreiro, em que os termos da aristeía são "o grito", "os pés velozes", a salvação do companheiro de armas ou o retirar do seu cadáver, e o saque das armas inimigas. O homem que detém todos esses traços de excelência, na épica homérica, é considerado o melhor por seus companheiros. Esses mesmos

33 O dolo e a perfídia como instrumentos para se ganhar uma guerra (ou uma batalha pessoal) é tema recorrente em Heródoto e na literatura grega em geral. O mais célebre exemplo é o estratagema do cavalo de madeira que fez ruir Tróia. De forma parecida, o reino da rainha masságeta Tómiris foi alvo de um expediente, primeiro quando Ciro pede-a em casamento com o intuito de tomar seu reino (Heródoto 1.205), depois quando usa o vinho e um banquete para neutralizar a força do inimigo (1.207). No plano pessoal, as tragédias Helena e Ifigênia entre os Tauros de Eurípides são um exemplo de como o ludíbrio pode vencer soberanos poderosos sem o uso de força. Vide supra 49-50. 
traços da aristeía sáo retomados no conto $A$ tribo (82): o grito guerreiro que amedronta o inimigo (Il. 5. 302, 591, 863); o retirar do guerreiro ferido ou morto do campo de batalha (Il. 5.296-301, 24. 469-691); a força e a coragem dos combatentes para obter fama gloriosa (Il. 5.01-03, 470); a ligeireza dos pés (82) (Il. 5.885, 16.5); o retirar as armas do oponente (Il. 5.435). Tais qualidades são recomendadas a Aquiles por seu pai: "que primasse pela valentia e fosse superior aos outros todos, para que não desonrasse a linhagem paterna" (Il. 6.208-209). O argumento de Aquiles, por seu lado, acrescenta-lhes a necessidade do herói épico de manter-se imortalizado através de seus feitos guerreiros. A interferência divina nos resultados da guerra entre os brancos e os negros, a "malquerença dos deuses" (82), da mesma forma é um motivo constante na Ilíada (15. 4 passim), agora retomado para a definição da aristeía de um povo.

Portanto, em ambos os contos, ressalta-se o valor da areté e da hierarquia social, mas em Ferzo temos um retrato do mundo ao avesso, em que contrapóe-se uma sociedade civilizada, urbanizada, paralela com a nossa, apenas com os valores ao contrário. Até mesmo as eleiçóes têm a estrutura do nosso mundo, porém com uma leitura inversa. Entretanto, a oposição extrema dos dois povos é uma falácia, porque há apenas uma relatividade de nomos, que, na concepçáo de seus habitantes, apresenta defeitos e vantagens. É o que Gat' pensa da organização daquela cidade (79): com a simbologia da troca dos remos de bordo para bordo, insinua que tudo é igual. Esse parece ser o retrato de nossa própria civilização, em que se imortalizam a banalidade e o ordinário. Porém, essa inversão de princípios (ou a vida em negativo) nada pode resolver, porque ela também tenderá para a mediocridade humana e civilizacional.

A mesma relatividade de nomos e de areté ocorre no conto $A$ tribo: ingenuamente decidem enviar um grande guerreiro para ter com os brancos, assim estes não iriam querer mais guerrear (83). Todavia, o chefe branco afirma que: "Temos de correr com aqueles ranhosos dos pretos para o deserto, que estão a ocupar muito espaço" (83). Na verdade, os Bantshwanas ignoravam que seus feitos ilustres, sua honra e seu nomos não tinham o menor valor para o arrogante exército dos brancos. Logo, o sentido de areté dessa tribo assenta na superioridade física, no respeito pelo adversário, na agilidade e na capacidade de mutaçáo e de resistência, e o do exército branco na quantidade de armas, de cavalos ou homens de um exército, em uma total falta de simetria em relação ao nomos e ao modo de guerrear dos Bantshwanas. Heródoto usa exatamente os mesmos critérios para distinguir os povos civilizados dos selvagens: os Persas impóem-se pelo número, 
pela variedade de batalhóes (1. 103, 3.25, 4.83), enquanto os "bons selvagens" (Masságetas, Etíopes e Citas) pela superioridade física (3.17-18, 21), resistência $(4.126,131)$, finura (1. 206). Os contos traduzem duas leituras contraditórias, que servem à verdade que cada um queira ver: essa é a "moralidade" que se quer transmitir, a noção de que a verdade é relativa.

Em conclusão, entendemos que esses textos discutem, de forma simbólica, o "estar no mundo" de personagens que representam o Homem "cercado" por um universo opressivamente restrito, que por isso mesmo são guiados a uma "re-velaçáo" ou a um "des-velamento" 34 de sua própria condição. Assim, o jogo entre luz/trevas, conhecimento/ignorância, riqueza/ pobreza, homem comum/poeta-profeta, mundo interior/ mundo exterior são constantes na narrativa, que se orienta sempre para a demonstração de que não há uma verdade ou um conhecimento único, além de exprimir uma clara insatisfação com a moderna civilização ocidental dentro de cuja cultura são pensados. A análise geral da temática da viagem e do 'outro' em Fabulário demonstrou, através da fantasia (e do fantástico), ${ }^{35}$ da relativização e da "moralidade" própria da fábula, um panorama da própria crise civilizacional a que estamos submetidos, porque "a ficção, entendida como um discurso de alteridade, justamente por isso se presta à crítica aos mais diversos aspectos da cultura e da sociedade; portanto, falar de ficção supóe sempre falar de sociedade e cultura (...)"36.

34 Empregamos os termos usados por Fialho, M. C. (1992), Luz e trevas no teatro de Sófocles. Coimbra, Instituto Nacional de Investigação Científica: 72.

35 Cf. a definição dos termos que adotamos na Introdução.

36 Brandão, J. L. (2001), A poética do Hipocentauro. Belo Horizonte, Ed. UFMG: 27. 


\section{Bibliografia Geral}


(Página deixada propositadamente em branco) 


\section{Ediçôes de Mário de Carvalho}

(21990), Contos da sétima esfera. Lisboa, Caminho.

(1991), Quatrocentos mil sestércios. Lisboa, Caminho.

(71991), Casos do beco das sardinheiras, Lisboa, Caminho.

(31993), A Paixão do Conde de Fróis. Lisboa, Caminho.

(1996), Os Alferes. Lisboa, Caminho.

( $\left.{ }^{3} 1996\right)$, O livro grande de Tebas, Navio e Mariana. Lisboa, Caminho.

(1997), Um deus passeando pela brisa da tarde, Lisboa, Caminho.

$\left({ }^{3} 1997\right)$, Fabulário. Lisboa, Caminho.

(52003), Era bom se trocássemos umas ideias sobre o assunto. Lisboa, Caminho.

(32004), Fantasia para dois Coronéis e uma Piscina. Lisboa, Caminho.

('2006), A inaudita guerra da Avenida Gago Coutinho. Lisboa, Caminho.

(2008), A sala magenta. Lisboa. Caminho.

(2010), A Arte de Morrer Longe. Lisboa, Caminho.

\section{Estudos}

Adorno, T. W. ('1983), "Posição do narrador no romance contemporâneo". In: Benjamin, Honkheimer, Adorno, Habermas. Trad. port. José L. Grünnewald et alii. São Paulo, Abril Cultural: 269-273.

Albaladejo, T. (1986), Teoría de los mundos posibiles y macroestructura narrativa. Alicante, Universidade de Alicante.

Albaladejo, T. (1992), Semántica de la narración: la ficción realista. Madrid, Taurus.

Albérès, R. M. (1972), Métamorphoses du roman. Paris, Albin Michel.

Almeida, J. F. (1997), Bíblia Sagrada. Rio de Janeiro, Fecomex (Ed. Revisada e corrigida).

Alves, C. C. (2010) "Vestígios do trágico em Mário de Carvalho”. Navegaçôes 3. 1: 53-58.

Anacleto, M. T. (1996), “(Sub)versions du "cliché” romanesque au XVII siècle: le "roman bourgeois" de Furetière”, Confluências 14: 97-109.

Angelini, P. R. K. (2011) "Recensão de Carvalho, M. A arte de morrer longe. Lisboa, Caminho, 2010. 128p.”. Navegaçōes 4. 1: 131-133.

Arnaut, A. P. (2001), "Donas e donzelas n'a Demanda do Santo Graal”, Santa Barbara Portuguese Studies. Califórnia, n. 5: 29-71. 
Aristófanes (21989), A Paz. Tradução de Silva. M. F. Coimbra, Instituto Nacional de Investigação Científica.

Aristófanes (2006), As Aves. Tradução de Silva, M. F. Lisboa, Edições 70.

Aristóteles (1986), Poética. Tradução de E. Sousa. Lisboa, Fundação Gulbenkian.

Arnaut, A. P. (2002), Post-Modernismo no romance português contemporâneo. Fios de Ariadnemáscaras de Proteu. Coimbra, Almedina.

Assis, A. K. T. (2008), Arquimedes, o centro de gravidade e a lei da alavanca. Montreal, Apeiron Montral.

Auerbach, E (1976), Mimesis (A representação da realidade na literatura ocidental). São Paulo, Perspetiva [1 $1^{\text {a }}$ ed., 1946].

Aurélio, Marco (1971), Pensamentos. Versão de João Maia. Lisboa, Editorial Verbo.

Bakhtine, M. (1970), La Poétique de Dostoievsky. Paris, Éd. du Seuil.

Bakhtine, M. (1981), Dialogic imagination: four essays. Austin, University of Texas Press.

Bakthine, M. (1981), Problemas da poética de Dostoievski. Trad. port. Paulo Bezerra. Rio de Janeiro, Ed. Forense-Universitária.

Benjamin, W. (1985), "Sobre o conceito de História. Tradução de Sérgio Paulo Rouanet”. In: Obras escolhidas. Magia e técnica, arte e política. São Paulo, Editora Brasiliense: 222-232.

Bessière, J. (2010), Le roman contemporain ou la problemacité du monde. Paris, PUF.

Beye, C. R. (1964), "Homeric battle narrative and catalogues", Harvard Studies in Classical Philology 68: 345-373.

Bergson, H. (2001), O riso: ensaio sobre a significação da comicidade. Trad. port. Ivone C. Benedetti. São Paulo, Martins Fontes.

Bhabha, H. K. (1998), O local da cultura. Belo Horizonte, Editora UFMG.

Bianchet, S. B. (2004), Petrônio. Satyricon. Edição bilíngüe. Belo Horizonte, Crisálida.

Bougnoux, D. (1991), "Le principe d'identification”. In Personnage et Histoire Littéraire. Toulouse, Presses Universitaires du Mirail: 187-195.

Brandão, J. L. (2001), A poética do Hipocentauro: Literatura, sociedade e discurso ficcional em Luciano de Samósata. Belo Horizonte, Ed. UFMG.

Brasete, M. F. (2003), “A crítica às mulheres no fr. 7 de Semónides de Amorgos”. In: Mora, C. M. (ed.), Sátira, Paródia e Caricatura: da Antiguidade aos nossos dias. Aveiro, Universidade de Aveiro: 39-56.

Brauner, E. F. (2009), “" Era bom que trocássemos umas ideias sobre o assunto”: ironia de um narrador e discussão do romance", Revista Electrónica de critica e teoria de literaturas. Dossiê: o romance português e o mundo contemporâneo 5. 2. Porto Alegre: 1-9.

Buescu, H. (1995), A Lua, a Literatura e o Mundo. Lisboa, Cosmos. 
Buescu, M. L. C. (1979), Aspectos da herança clássica na cultura portuguesa. Lisboa, Instituto de Cultura Portuguesa.

Camôes, L. (1979), Os Lusíadas. Prefácio de Hernâni Cidade. São Paulo, Abril Cultural.

Carcopino, J. (1993), La vida cotidiana en Roma en el apogeo del imperio, trad. esp. Madrid, Ediciones Temas de Hoy.

Cardoso Bernardes, J. A. (1988), O Bucolismo Português. A égloga do Renascimento e do maneirismo. Coimbra, Livraria Almedina.

Carvalho, M., (2003), "Mário de Carvalho: crónica do aturdimento". JL - Jornal de Letras, Artes e Ideias 864, 12/11: 12.

Ceia, C. (2007), A Construção do romance (Ensaios de literatura comparada no campo dos estudos anglo-portugueses). Coimbra, Almedina.

Chevalier, J., Gheerbrant, A. (1994), Dicionário dos Símbolos, trad. port., Lisboa, Editorial Teorema.

Colaço, J. (1995), “Mário de Carvalho”, Biblos. Enciclopédia verbo, I, s.u.

Compagnon, A. (2001), O demônio da teoria: Literatura e senso comum. Belo Horizonte, Editora UFMG.

Constâncio, N. (2007), Ruinas e incertezas em "Um Deus passeando pela brisa da tarde”, de Mário de Carvalho. Lisboa, Edições Colibri.

Costa, L. S. (1995), “Era Bom que Trocássemos Umas Ideias Sobre O Assunto, de Mário de Carvalho. A Arquitectura, A Violência”. In: Público/Leituras, 11 de Novembro:10.

Cotrim, J. P. (1996), Entrevista a Mário de Carvalho: "Alguma coisa me perturba”. Ler/Livros e Leitores 34: 45.

Cotrim, J.P. (1996), "Mário de Carvalho. O Mistério da Literatura”, entrevista ao autor. LER 34, Primavera.

Cristóbal, V. (1992), "Búsqueda de campo, hastío de ciudad. Pasión antigua y contemporánea”. In: Guzmán, A. et alii (ed.), Aspectos modernos de la Antigüedad y su aprovechamiento didáctico. Madrid, Ediciones Clásicas: 131-143.

Davison, M. (1976), "The thematic use of ekphrasis in the ancient novel”, in Erotica antiqua. Acta of the International Conference on the Ancient Novel. Bangor, ICAN: 32-33.

Devereux, G. (1975), Dreams in Greek tragedy. Oxford, Basil Blackwell.

Dijksterhuis, E. J. (1987), Archimedes. Translated by C. Dikshoorn. Princeton University Press.

Diogo, A. A. L. (1997), "Exórdio". In: Biblos- Enciclopédia Verbo das Literaturas de Lingua Portuguesa. Lisboa, São Paulo, Verbo.

D’Onofrio, S. (1978), Poema e Narrativa: estruturas. São Paulo, Duas Cidades. 
Duncan, T.S. (1935), “The deus ex machina in Greek Tragedy”. Philological Quarterly 14: $126-141$.

Dunn, F. M. (1985), Euripidian Endings: a Study of the Choral Exit, the Action, the Concluding Prophecy and the Deus ex Machina. Yale University: 111-167.

Eco, U. (1979), Leitura do Texto Literário. Lector in Fabula. Trad. Mário Brito. Lisboa, Presença.

Entrevista com Mário de Carvalho http://www.homemmag.pt/pt/index.php/arte-e-literatura/arquivo-arte-literatura/87-luisa-costa-gomes-entrevista-mario-de-carvalho

Ernout, A. ( $\left.{ }^{11} 1993\right)$, Pétrone. Le Satyricon. Paris, Les Belles Lettres.

Ernout A, Meillet, A. ( $\left.{ }^{4} 1967\right)$, Dictionnaire etymologique de la langue latine: histoire des mots. Paris, Librairie C. Klincksieck.

Errandonea, I. (1954), Diccionario del mundo clásico. Barcelona, Editorial Labor.

Eschilo ( $\left.{ }^{4} 2000\right)$ I sette contro Tebe. Con testo a fronte. Introd. Umberto Albini. Trad. Ezio Savino. Milano, Garzanti Editore.

Feijóo, B. (1998), Um Não Sei Quê. Lisboa, Vega [1746].

Ferreira, C. (2003), “Mário de Carvalho. A arte de bem iludir o leitor”. In: Rodapé: 45-51.

Ferreira, P. S. (1999), “A paródia e as suas implicações didácticas”. In: Torrão, J. M. N. (ed.), III Colóquio Clássico - Actas. Aveiro, Universidade de Aveiro: 113-137.

Ferreira, P. S. (2000), Os elementos paródicos no Satyricon de Petrónio e o seu significado. Lisboa, Colibri.

Ferreira, P. S. (2003), “Paródia ou paródias?”. In: Mora, C. M. (ed.), Sátira, Paródia e caricatura: da Antiguidade aos nossos dias. Aveiro, Universidade de Aveiro: 279-300.

Fialho, M. C. (1992), Luz e trevas no teatro de Sófocles. Coimbra, Instituto Nacional de Investigação Científica.

Figueiredo, M. N. (2006), "Com humana crueldade se tece um conto. A propósito de Homenagem ao Papagaio Verde”. In: Santos, G. (ed.) Jorge de Sena: Ressonâncias e Cinqüenta Poemas. Rio de Janeiro, 7Letras.

Fowler, D. P. ((1991), "Narrate and describe: the problem of ecphrasis", Journal of Rhetorical Studies 81: 25-35.

Frow, J. (1986), “Spectacle Binding: On Character”. Poetics Today 7. 2: 227-250.

Gaffiot, F. (1934), Dictionnarie Illustré Latin-Français. Paris, Librairie Hachette.

Garrett, A. (1973), Viagens na minha Terra. Rio de Janeiro, Editora Três.

Genette, G. (1972), Figures III. Paris, Ed. du Seuil.

Gennete, G. (1997), L'Cuvre de l'Art. La Relation Esthétique, II. Paris, Ed. du Seuil.

Genette, G. (2004), Métalepse. Paris, Ed. du Seuil.

Gomes da Torre, M. (1992), “Acerca da tradução da metáfora”. Linguas e Literaturas 9: 209-226. 
Grimal, P. (s/d), Dicionário de Mitologia Grega e Romana. Lisboa.

Guillén, J. (1977), Vrbs Roma - vida e costumbres de los romanos, vol. I: La vida privada. Salamanca, Ediciones Sígueme.

Guthrie, W. K. C. (1976), Les Sophistes. Paris, Payot.

Halliwell, S. (1968), Aristotle's Poetics. Chicago and London.

Hamon, P. (1976), “O que é a descrição?”. In: Seixo, M. A. (ed.), Categorias da narrativa. Lisboa, Arcádia: 61-83.

Hardwick, L. (2003), Reception Studies. Greece and Rome. New Surveys in the Classics. Oxford, Oxford University Press. [recensão do livro por Martin M. Winkler, in Bryan Mawr Classical Review 2004].

Heródoto. (2002), Histórias. Livro I. Tradução de Ferreira, J. R., Silva, M. F. Lisboa, Ediçóes 70. Heródoto (1997), Histórias. Livro III. Tradução de Silva, M. F., Abranches, C. Lisboa, Ediçóes 70. Heródoto (2000), Abranches, C., Histórias. Livro IV. Tradução de Silva, M. F., Abranches, Lisboa, Edições 70.

Homero (2003), Odisseia. Tradução de Frederico Lourenço. Lisboa, Livros Cotovia.

Homero (2005), Ilíada. Tradução de Frederico Lourenço. Lisboa, Livros Cotovia.

Hoorn, J. F., and Konijn, E. A. (2003), "Perceiving and experiencing fictional characters: An integrative account”. Japanese Psychological Research 45. 4: 250-268.

Horácio (1975), Arte Poética. Tradução de R. M. R. Fernandes. Lisboa, Clássica Editora.

Hutcheon, L. (1977), “Modes et formes du narcisisme littéraire”. Poétique 29: 90-106.

Hutcheon, L. (1984), Narcissistic Narrative. The Metafictional Paradox. New York and London, Methuen.

Hutcheon, L. (1985), A Theory of Parody. The Teachings of Twentieth Century Art Forms. New York \& London, Methuen; (1989), Uma teoria da paródia, trad. port. Lisboa, Ediçóes 70.

Hutcheon, L. (1988), A poetics of Postmodernism. History, Theory, Fiction. New York/London, Routledge; (1991), Poética do Pós-Modernismo. Trad. Ricardo Cruz. Rio de Janeiro, Imago.

Hutcheon, L. (2000), Teoria e Política da Ironia. Trad. port. Julio Jeha. Belo Horizonte, Editora UFMG.

Immerwahr, H. R. (1966), Form and thought in Herodotus. University of North Carolina.

Izaac, H. J. ( ${ }^{3} 1969$, 1973), Martial. Épigrammes, I-II. Paris, Les Belles Lettres.

Jauss, H. R. (1986), Experiencia y Hermeneutica Literaria. Ensayos en el campo de la experiencia estétca. Madrid, Taurus, [1977].

Jenny, L. (1979), "A estratégia da forma”, Poétique. Revista de teoria e análise literárias. Trad. port. Clara C. Rocha. Coimbra, Almedina: 5- 49. 
Jerome, K. J. , “Three men on the Brummel'. In: http://www.gutenberg.org/catalog/world/ readfilefk_files $=2061881$

Jourdan, P. (1996), "Paul Valéry chasseur de perroquets", Confluências 14: 51-59.

Júdice, N. (1997), Viagem por um século de Literatura Portuguesa. Lisboa, Relógio d'Água.

Julien, Y. (1998), Aule-Gelle. Les nuits attiques, IV. Paris, Les Belles Lettres.

Jurado, F. G. (1999), "Apuntes para una historia prohibida de la literatura latina en el siglo XX: La voz de los lectores no académicos”. In: Morán, M. C. A.; Iglesias Montiel, R. M. (eds.), Contemporaneidad de los clásicos en el umbral deI tercer milenio. Actas deI Congreso Internacional Contemporaneidad de los clásicos: La tradición greco-latina ante el siglo XXI. La Habana, Universidad de Murcia: 77-85.

Kerferd, G. B. (2003), O movimento sofista. Trad. port. Margarida Oliva. São Paulo, Ediçôes Loyola.

Kirk, D. M. (1960), The digression, its use in prose fiction from the Greek romance through the eighteenth century. Stanford University.

Kristeva, J. (1974ª), Introdução à semanálise. São Paulo, Perspectiva.

Kuester, M. (1992), Framing Truths - Parodic Structures in Contemporary English-Canadian Historical Novels. Toronto/London, Toronto University Press.

Lausberg, H. (1963), Elementos de retórica literária. Trad. port. Raul M. Rosado Fernandes, Lisboa, Gulbenkian.

Leão, D. F. (1996), “Trimalquião: a humanitas de um novo-rico”. Humanitas 48: 161-182.

Leão, D. F. (1997), “Trimalquião à luz dos Caracteres de Teofrasto”. Humanitas 49: 147-167.

Leão, D. F. (1998), As Ironias da Fortuna. Sátira e Moralidade no Satyricon de Petrónio. Lisboa, Colibri.

Leão, D. F. (2004), “Zoilo e Trimalquião, duas variaçôes sobre o tema do novo-rico”. Humanitas 56: 191-208.

Leão, D. F. (2004a), “O Satyricon de Petrónio e a crise dos paradigmas tradicionais”. In: Nascimento, A. (ed.), Antiguidade Clássica: Que fazer com este património?. Lisboa, Centro de Estudos Clássicos: 233-242.

Leão, D. F. (2005), Petrónio. Satyricon. Lisboa, Cotovia.

Lepaludier, L (2002), Métatextualité et métafiction. Théorie et analyses, Presses Universitaires de Rennes, CRILA.

Levi, P. (1988), É isto um homem? Rio de Janeiro, Rocco.

Lévy, E. (1983), "Le théâtre et le rêve: le rêve dans le théâtre d'Eschyle", in Zehnacker, H. (ed.), Théatre et spectacles dans l'Antiquité. Actes du Colloque de Strasbourg. Leiden: 141-168.

Lopes, S. R. (2003), Literatura, Defesa do atrito. Lisboa, Copiart. 
Lourenço, E. ('1982), "Da literatura como interpretação de Portugal”. In O Labirinto da Saudade (Psicanálise Mitica do Destino Português). Lisboa, D. Quixote: 85-126.

Lourenço, F. (2003), Homero. Odisseia. Lisboa, Cotovia.

Luciano (1996), Uma história verídica. Tradução de C. Magueijo. Lisboa, Editorial Inquérito Limitada.

Lukács, G. (1989), Théorie du roman. Paris, Flammarion [1916].

"Na Lusitânia com Mário de Carvalho (História, paródia e ironia em Quatrocentos mil sestércios e Um deus passeando pela brisa da tarde)". In Veredas 5 (2002) 211-224.

Macedo, A. G. (2008), Narrando o pós-moderno: reescritas, revisôes, adaptaçôes. Braga Universidade do Minho.

Machado, J. P. (1995), Dicionário etimológico da Língua Portuguesa. Lisboa, Livros Horizonte.

Malina D. (2002), Breaking the frame: metalepsis and the construction of the subject. Columbus, Ohio State UP.

Margolin, U. (2005), “Character”. In: Herman, D., Jahn M., Ryan, M.-L. (eds.), Routledge Enciclopedia of Narrative Theory. London/New York, Routledge: 54-57.

Marinho, M. F. (1996), "O sentido da história em Mário de Carvalho", Revista da Faculdade de Letras. Linguas e Literaturas: 257-267.

Marinho, M. F. (2010), "À la recheche de l'identité perdue. Essai sur la crise d'identité dans le roman portugais contemporain”. In: Besse, M. G. \& Ralle, M. (eds.), Les Grands Récits: Miroirs Brisés? Paris, Índigo:186-198.

Martin, F. (1987), Les mots latins. Paris, Hachette.

Martins, J. C. O. (2011), "Mário de Carvalho e a reflexão metaficcional sobre o futuro do romance”. Diacrítica. Dossiê Literatura e Religiāo 25/3: 23-44.

Martins, J. C. O. (2011), “Pensar Portugal - ironia, paródia e desencanto: Mário de Cavalho e o retrato melancólico de um país". In: Carvalho da Silva, J. A., Martins, J. C. O., Gonçalves, M. (eds.), Pensar a Literatura no Séc. XXI. Braga, Univ. Católica Portuguesa: 463-478.

Martins, J. C. O. (s.d.), "La barbarie de l'ignorance dans la culture postmoderne et la fiction de Mário de Carvalho". In: De l'Extrême: pratiques du contemporain dans les mondes ibériques et ibéro-américains, Paris, CRIMIC [em publicação].

Martins, M. F. (1983), Sombras e transparências da literature. Lisboa, INCM.

Martins, Maria João (2003), "Mário de Carvalho: crónica de um aturdimento" [entrevista], JL - Jornal de Letras, Artes e Ideias, no 864, 12 novembro, p. 12.

Mead, G. (1990), “The Representation of Fictional Character”. Style 24. 3: 440.

Medeiros, W. (1997), "Do desencanto à alegria: o Satyricon de Petrónio e o Satyricon de Fellini”. Humanitas 49: 169-175. 
Melanda, P. C. O. (2001), Pela mão de Clio. A reescrita da História em Mário de Carvalho. Aveiro. 38. Dissertação de Mestrado em Estudos Portugueses, apresentada à Universidade de Aveiro. Exemplar em CDRom.

Melero Bellido, A. (2001), "La utopia cómica o los límites de la democracia”, Cuadernos de Literatura Griega y Latina 3: 7-25.

Melero Bellido, A. (2004), "La lengua de la utopia". In: López Eire, A., Guerrera, A. R. (Eds.). Registros Lingüísticos en las lenguas clásicas. Salamanca, Ediciones Universidad Salamanca: 149-172.

Mendes, A. M. G. (1999), "Cultura clássica em Um Deus Passeando pela brisa da tarde de Mário de Carvalho”, III Colóquio Clássico - Actas, Aveiro: 347-363.

Mendes, A. M. G. (2005), “Trimalquião, os coronéis e a piscina: retrato impiedoso de um país em crise”. Ágora. Estudos Clássicos em Debate. Aveiro 7: 129-150.

Mendes, J. P. (1997), Construção e Arte das Bucólicas de Virgílio. Coimbra, Almedina.

Mendonça, F. (1997), “A Paixão do Conde Fróis”. Colóquio/Letras 99. Setembro-Outubro.

Mexia, P. (2005), “O Manuel Germano”. Diário de Notícias. Artes, 17 de Junho: http:// dn.sapo.pt/2005/06/17/artes/o_manuel_germano.html

Moisés, M. ('1973), A criação literária: introdução à Problemática da Literatura. São Paulo, Melhoramentos.

Mora, C. M. (2003), “A outra resposta de Tirésias”. In: Mora, C. M. (ed.), Sátira, Paródia e caricatura: da Antiguidade aos nossos dias. Aveiro, Universidade de Aveiro: 7-13.

Morais e Silva, A. (1953), Grande Dicionário da Lingua Portuguesa. Lisboa, Confluência.

Mourão, J. A. (1998), "Posfácio”, a Feijóo, Benito - Um Não Sei Quê. Lisboa, Vega.

Nickel, R. (1999), “Lucian's True Story: impressions of a fancy voyage”, Euphrosyne 27: 249-257.

Niederauer, S. (2008), "Era bom que trocássemos umas ideias sobre o assunto ou $\mathrm{O}$ simulacro da narrativa na pós-modernidade”. Letras de Hoje 43. 4: 83-88.

Oliveira, B. S. (1997), Eurípides. Hipólito. Brasília, Editora UNB.

Onelley, G. B. (2004), “A resistência da nau: cidade na luta pelo poder”. Calíope 12: 33-42.

Otte, G. (1996), "Rememoração e citação em Walter Benjamin". Revista de Estudos de Literatura 4. Belo Horizonte, Centro de Estudos Literários (CEL), Faculdade de Letras da UFMG: 211-223.

Pereira, E. (2003), "Viagens na minha terra: ciladas da representação". Revista do Centro de Estudos Portugueses 23 n. 32: 61-68.

Pereira, S. M. (2008), “Poética dos sonhos e das visōes em estado de vigília - I”, Humanitas 60: 11-28.

Pereira, S. M. (2009), "Poética dos sonhos e das visōes em estado de vigília - II”, Humanitas 61: 5-18.

Perelman, C. O. (1993), O Império Retórico: Retórica e Argumentação. Tradução de Fernando Trindade e Rui Alexandre Grácio. Porto, Ediçóes Asa. 
Perrin-Naffakh. A.-M. (1996), "Le langage cliché: aveu d'usure ou pouvoir d'écho". Confluências 14: 7-14.

Perrone-Moisés, L. (1979), “A intertextualidade crítica”. Poétique. Revista de teoria e análise literárias. Trad. port. Clara C. Rocha. Coimbra, Almedina: 209-230.

Pimentel, C. S. (2001), "O latim nas literaturas portuguesa e francesa: instrumentos, métodos e agentes de ensino”, Ágora, Estudos Clássicos em Debate 3: 183-185.

Piwnik, M.-H. (1998), "Mário de Carvalho: crónica de um desfecho anunciado", Veredas 1, Porto: 317-325.

Piwnik, M.-H. (2004), “De Sienkiewicz a Mário de Carvalho: Duas construções da História”. In: Literatura e História. Actas do Colóquio Internacional, Porto, vol. II: 139-144.

Platão ( $\left.{ }^{12} 2010\right)$, República. Trad. Maria Helena da Rocha Pereira. Lisboa, Fundação Calouste Gulbenkian.

Préchac, F. (1987), Sénèque. Lettres a Lucilius, II. Paris, Les Belles Lettres.

Queirós, E. de (s./d.), Os Maias. Lisboa, Livros do Brasil.

Queirós, E. de (2000), O Crime do Padre Amaro. Ed. crítica de Carlos Reis e M. Rosário Cunha. Lisboa, IN-CM.

Rabaté, E. (1996), "Henri Michaux et le cliché: résistance et fascination”. Confluências 14: 61-75.

Raimond, M. (1989), Le Roman. Paris, Armand Colin.

Reis, C. (1996), "Mário de Carvalho. Incitação ao romance”. Jornal de Letras 28 Agosto: 22-23.

Reis, C. (1997), "Fábula”. In: Biblos-Enciclopédia Verbo das Literaturas de Lingua Portuguesa. Lisboa, São Paulo, Verbo: 462-463.

Reis, C. (2005), História crítica da literatura portuguesa, vol. IX (Do neorrealismo ao postmodernismo). Lisboa, Verbo: 287-318.

Reis, C., Macário Lopes, A. C. (72007), Dicionário de narratologia. Coimbra, Almedina.

Ricoeur, P. (1983), Temps et Récit. T.I. Paris, Ed. du Seuil.

Rio Torto, G. M. (1996), "Linguagem e clichê", Confluências 14: 159-175.

Robilliard, M.-A. (2002), Água em pena de pato de Mário de Carvalho. Um teatro do desencanto. Trad. port. Manuel Ruas. Lisboa, Editorial Caminho.

Rocha Pereira, M. H. (1955), Concepçōes Helénicas de felicidade no além: de Homero a Platão. Coimbra, Maranus.

Rocha Pereira, M. H. (1980), Poesia Grega Arcaica. Coimbra, Instituto de Estudos Clássicos.

Rocha Pereira, M. H. (1984), Estudos de História da Cultura Clássica, vol. II (Cultura Romana). Lisboa, Fundação Calouste Gulbenkian.

Rocha Pereira, M. H. ('1994), Romana - Antologia da Cultura Latina. Coimbra, Universidade de Coimbra. 
Rocha Pereira, M. H. ( $\left.{ }^{10} 2006\right)$, História da Cultura Clássica, I (Cultura Grega). Lisboa, Fundação Calouste Gulbenkian.

Rodrigues, L. G. (2005), “A Radioestesia”. In http://rprecision.logspot.com/2005/06/radiestesia.html Rose, M. A. (1979), Parody and meta-fiction. London, Croom Helm.

Sant'Anna, A. R. ('1985), Parodia, paráfrase \& cia. São Paulo, Ática.

Santos, R. B. (2009), Aspectos da Herança Clássica em Mário de Carvalho. Belo Horizonte, Faculdade de Letras da UFMG, 2009. [versão policopiada].

Saramago, J. (1989), História do Cerco de Lisboa. Lisboa, Caminho.

Saramago, J. (1990), "História e Ficção”. Jornal de Letras, Artes e Ideias, 6 de Março.

Schaeffer, J. M. (1992), L'art de l'àge moderne. L'esthétique et la philosophie de l'art du XVIIIème siècle à nos jours. Paris, Gallimard.

Schmidt, W. (1963), Der Deus Ex Machina bei Euripides. Tübingen University.

Schwartz, J. (1981), Murilo Rubião: A poética do Uroboro. São Paulo, Editora Ática.

Scodel, R. (1999), Credible impossibilities. Conventions and strategies of verisimilitude in Homer and Greek tragedy. University of Michigan Press.

Sedlmayer, S., "Sinais de fogo, aviso de incêndio: ideias estéticas, históricas e literárias em Jorge de Sena e Walter Benjamin”. In: Revista Literatrua e Autoritarismo. Dossiê Walter Benjamin e a Literatura brasileira. Santa Maria, Universidade Federal de Santa Maria/ RS. Disponível em http://w3.ufsm.br/grpesqla/revista/dossie05/art_02.php

Seel, M. (1992), "Le langage de l'art est muet". In: Bouchindhomme, Ch., Rochlitz, R. (eds.), L'art Sans Compas. Redéfinitions de l'Esthétique. Paris, Éd. du Cerf.

Segurado e Campos, J. A. (1991), Cartas a Lucílio, Lisboa, Fundação Calouste Gulbenkian.

Seixo, M. A. (1995), "Mário de Carvalho. Romance, Humanismo e BD”, JL - Jornal de Letras, Artes e Ideias, 12. 4: 24-25.

Sena, J. http://www.letras.ufrj.br/lerjorgedesena/port/antologia/ficcao-e-teatro/texto.php?id=319

Sequeira, M. G. R. (1996), Aproximação a uma Leitura do Risivel em A Paixão do Conde de Fróis. Tese de Mestrado apresentada à Faculdade de Letras da Universidade do Porto (dact.).

Settis, S. (2006), El futuro de lo 'clásico'. Traducción de Andrés Soria Olmedo. Madrid, Abada Editores.

Silva, M. F. (1987), Critica do teatro na comédia antiga. Coimbra, INIC.

Silva, M. F. (2005), Ensaios sobre Euripides. Lisboa, Cotovia.

Silva, M. F. (2007), "A porta na comédia de Aristófanes: uma entrada para a utopia”. In: Ensaios sobre Aristófanes. Lisboa, Cotovia: 257-274. 
Silva, M. F. (2008), "Mensagens, cartas e livros no teatro grego antigo", in Matos, M. C. (ed.), Helénicos. Estudos em homenagem do Prof. Jean-Pierre Vernant (1914-2007). Lisboa, Ediçôes Távola Redonda: 227-260.

Silva, M. F. (2009), Utopias e distopias. Coimbra, Imprensa da Universidade.

Silvestre, O. M. (1998), "Mário de Carvalho: Revolução e Contra-revolução ou um passo atrás e dois à frente”. Colóquio/Letras 147/148: 209-229.

Silvestre, O. e Diogo, A. L. (1998), "Entrevista a Mário de Carvalho", in <http://www. ciberkiosk.pt>, arquivo, $\mathrm{n}^{\circ} 1$ (15 pp.).

Simões, M. J. (2006), “Atrevidas e desbordantes: as personagens em Mário de Carvalho”. In Figuras da Fiç̧ão. Coimbra, Centro de Literatura Portuguesa: 79-92.

Spivak, G. Ch. ('2003), “Can the subaltern speak?” In: Asheroft, B., Griffith, G., Tiffin, H. (eds.), The post-colonial studies reader. New York, Routledge.

Spivak, G. Ch. (1998), "Puede hablar elsujeto subalterno?”. Orbis Tertius 3. 6: 1-44.

Sterne, L. (1860), The Works of Lawrence Sterne. London, Henry Bohn.

Thomasson, A. (2003), "Fictional Characters and Literary Practices". British Journal of Aesthetics 43. 2, April:138-157.

Todorov, T. (1999), O homem desenraizado. Trad. Christina Cabo. Rio de Janeiro, Record.

Torrão, J. M. N. (ed.) (1999), III Colóquio Clássico. Aveiro, Universidade de Aveiro.

Tosi, R. (2000), Dizionario delle sentenze latine e greche. Milano, Biblioteca Universale Rizzoli.

Trindade, L. (2004), “Os excessos de Abril”, História 65: 20-31.

Valente, A. M. (2004), Aristóteles. Poética. Lisboa, Gulbenkian.

Várzeas, M. (2001), Silêncios no teatro de Sófocles, Lisboa, Cosmos.

Villeneuve, F. (1970), Horace. Odes et Epodes, I. Paris, Les Belles Lettres.

Xavier, L. G. (2007), O discurso da ironia. Lisboa, Novo Imbondeiro.

Walton, K. (1990), Mimesis as Make-Believe: On the Foundations of the Representational Arts. Cambridge Mass., Havard University Press.

Waugh, P. (2003), Metafiction. The Theory and Practice of Self-Conscious Fiction. London \& New York, Routledge [1984].

Wesseling, E. (1991), Writing History as a Prophet. Postmodernist Innovations of the Historical Novel. Amsterdam/Philadelphia, John Benjamins.

Wolff, F. (2004), “Quem é bárbaro?”. In: Novaes, A. (ed.), Civilização e Bárbarie. São Paulo, Companhia das Letras: 19-43.

Woods, J. (1974), The Logic of Fiction. Paris, Mouton; (2010), A Mecânica da fiç̧âo. Lisboa: Quetzal. Zagajewski, A. (2003), En la belleza ajena, trad. esp. A. E. Diaz-Pintado Hilario, Valencia, Pre-Textos. 